\title{
Cell wall formation in multinucleate pollen grains of Hordeum vulgare anthers cultured in vitro
}

\author{
KRYSTYNA IDZIKOWSKA and FORTUNAT MŁODZIANOWSKI \\ Institute of Biology, Adam Mickiewicz University, Poznań, Poland \\ (Received: March 19, 1979)
}

Abstract

Cell wall formation in several-nucleate pollen grains of Hordeum vulgare anthers cultured in vitro was initiated at the intine. The walls grew centripetally and branched, dividing pollen protoplast into a several-celled embryoid.

\section{INTRODUCTION}

During androgenesis in cereals cell wall formation in anomalously developing, several-nucleate pollen grains was generally visible under the light microscope (Clapham, 1971; Wenzel and Thomas, 1974; Wang Ching-Chu et al., 1973; De Buyser and Picard, 1975; Z e n k tele r, 1976).

According to W ills on et al. (1978), in anther culture of Hordeum vulgare the cell wall formed at the tri- to tetranucleate stage of microsporcs development, only occasionally bicellular microspores were also encountered. In our observations on the same material cell wall formation took also place in several- to multinucleate pollen grains. In this communication problem is studied at the subcellular level.

\section{MATERIAL AND METHODS}

Earley (Hordeum vulgare cv. Alsa) was grown in the greenhouse. The inthers with microspores either just before, or after the formation of

This study was supported by grant no. 0.9.1.3.-02-02 from the Polish Academy of Sciences. 
vacuole (Młodzianowski and Idzikowska, 1978) were cultured in vitro in order to induce the process of androgenesis. After 3-24 days of culture fragments of anthers were fixed in $6 \%$ glutaraldehyde in $0.1 \mathrm{M}$ cacodylate buffer at $6.8 \mathrm{pH}$ for 18 hours, at $4^{\circ} \mathrm{C}$, and postfixed with $2 \% \mathrm{OsO}_{4}$ in cacodylate buffer for 2 hours. After washing with the buffer, the preparations were stained with $2 \%$ uranyl acetate for 1 hour, dehydrated with ethanol, acetone and propylen oxide, and embedded in a mixture of Epon 812. Thin sections were cut on an LKB ultramicrotome and contrasted with uranyl acetate and lead citrate (R e y nolds 1963, Venable et al., 1965). Electron micrographs were made on JEOLCO microscope, type 7A.

\section{RESULTS AND DISCUSSION}

In several-nucleate pollen grains of Hordeum vulgare cultured in vitro the cell wall did not form via the cytokinetic spindle. Cell wall formation was initiated at the intine of the pollen grains. The thickened areas of forming walls were rich in various kinds of membranous and amorphous inclusions (Fig. 2). Such inclusions were later supersede by fine fibrillar material (Fig. 3a). The fully formed cell wall looked normla, with middle lamella, primary wall and plasmodesmata running across it (Fig. 4). Only few osmiophilic globules (produced by endoplasmic
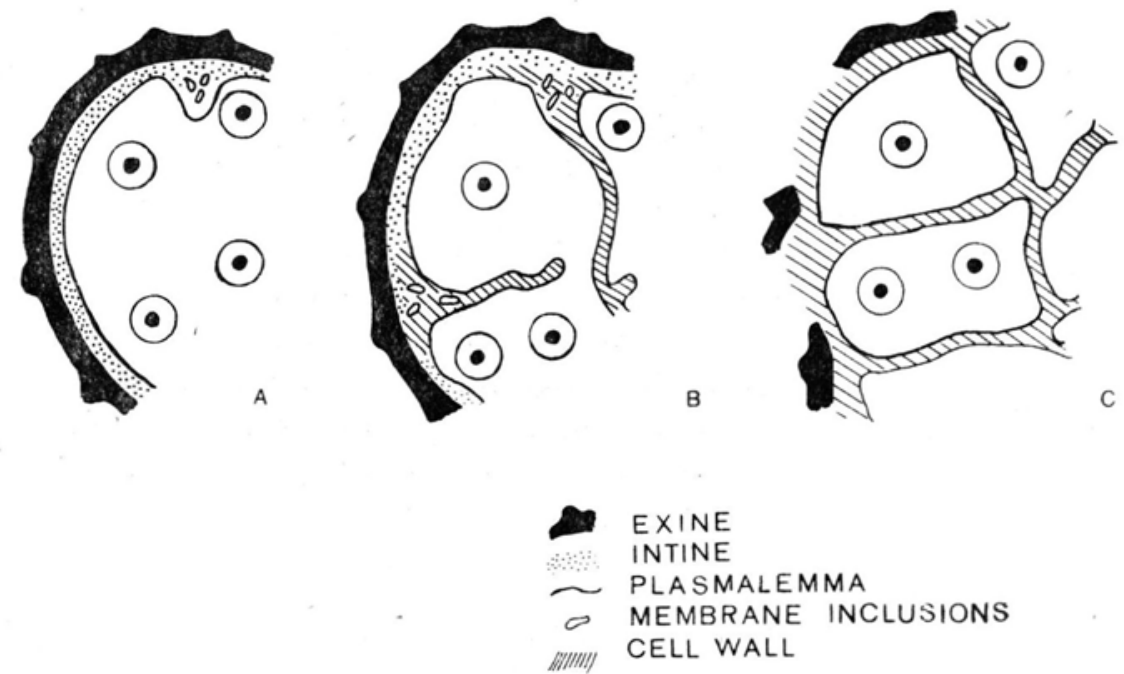

Fig. 1. Cell wall formation in multinucleate pollen grains of Hordeum vulgare cultured in vitro.

A. Fragment of multinucleate pollen grain, B. Cell wall formation, C. Fragment of multinucleate embryoid 


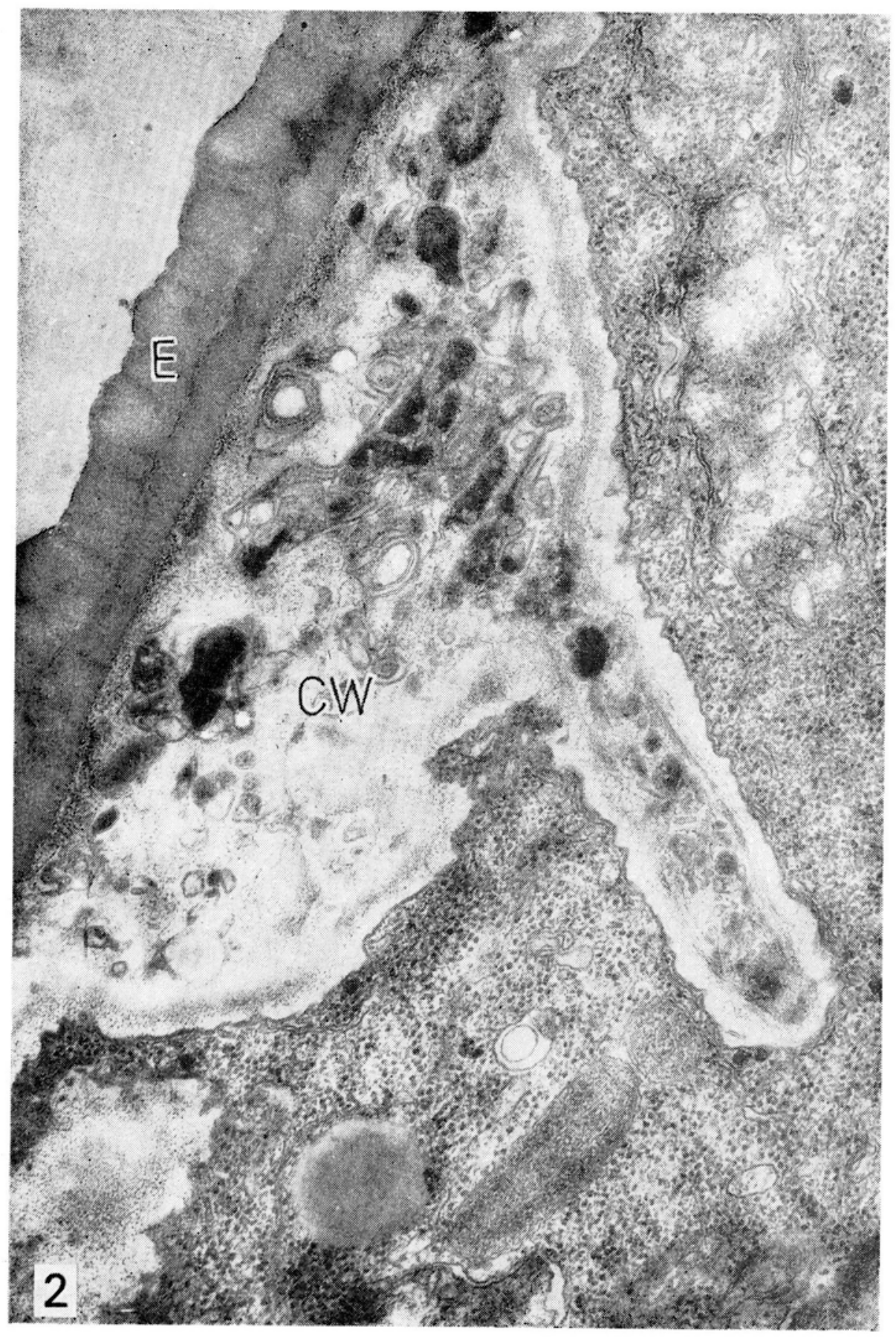

Fig. 2. Cell wall (CW) initial formed at the intine (I) contained many membraneous and amorphic inclusions.

$\mathrm{E}$ - exine, $(\times 35000)$ 


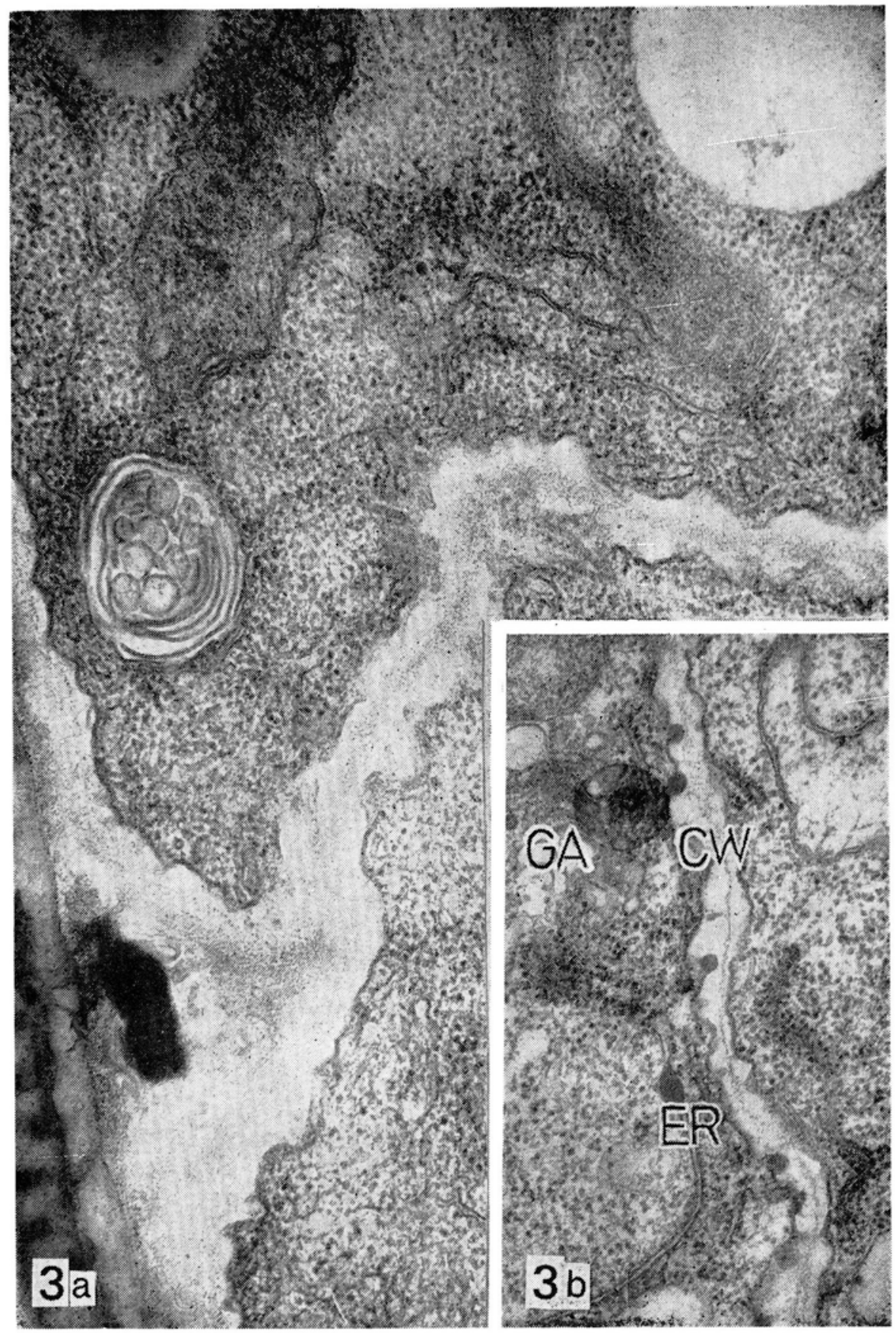

Fig. 3a. Cell wall inclusions superseded by fine fibrillar material (F). ( $\times 35000)$; b. Osmiophilic globules in endoplasmic reticulum (ER) and in cell wall (CW). GA Golgi apparatus. (X 35000$)$. 


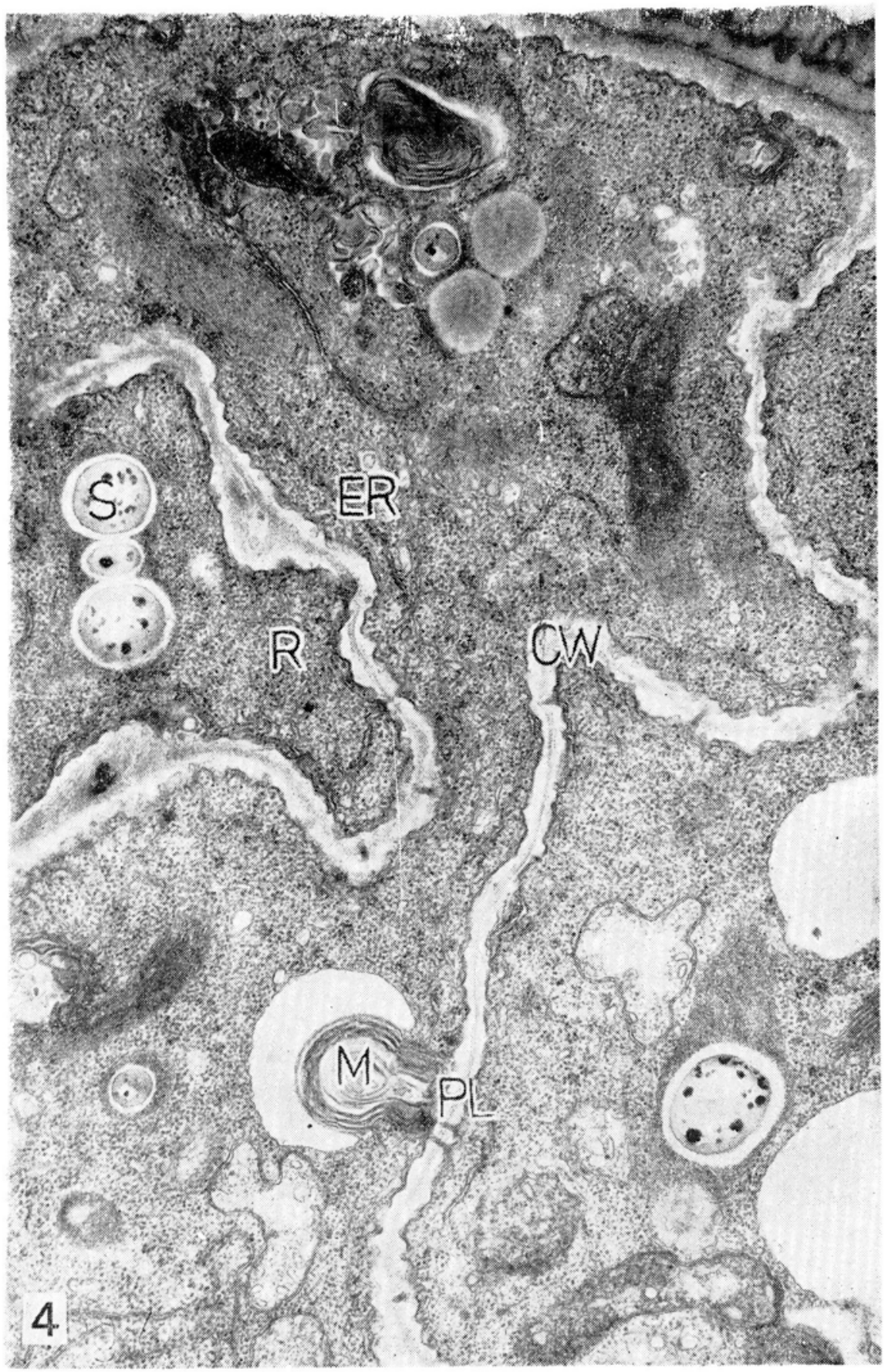

Fig. 4. Well developed cell wall (CW) surrounding dense cytoplasm rich in ribosomes (R) of the multicelled embryoid.

M - myelin-like structure, ER - endoplasmic reticulum, Pl - plasmodesmata, $\mathrm{S}-$ starch. $(\times 22500)$. 


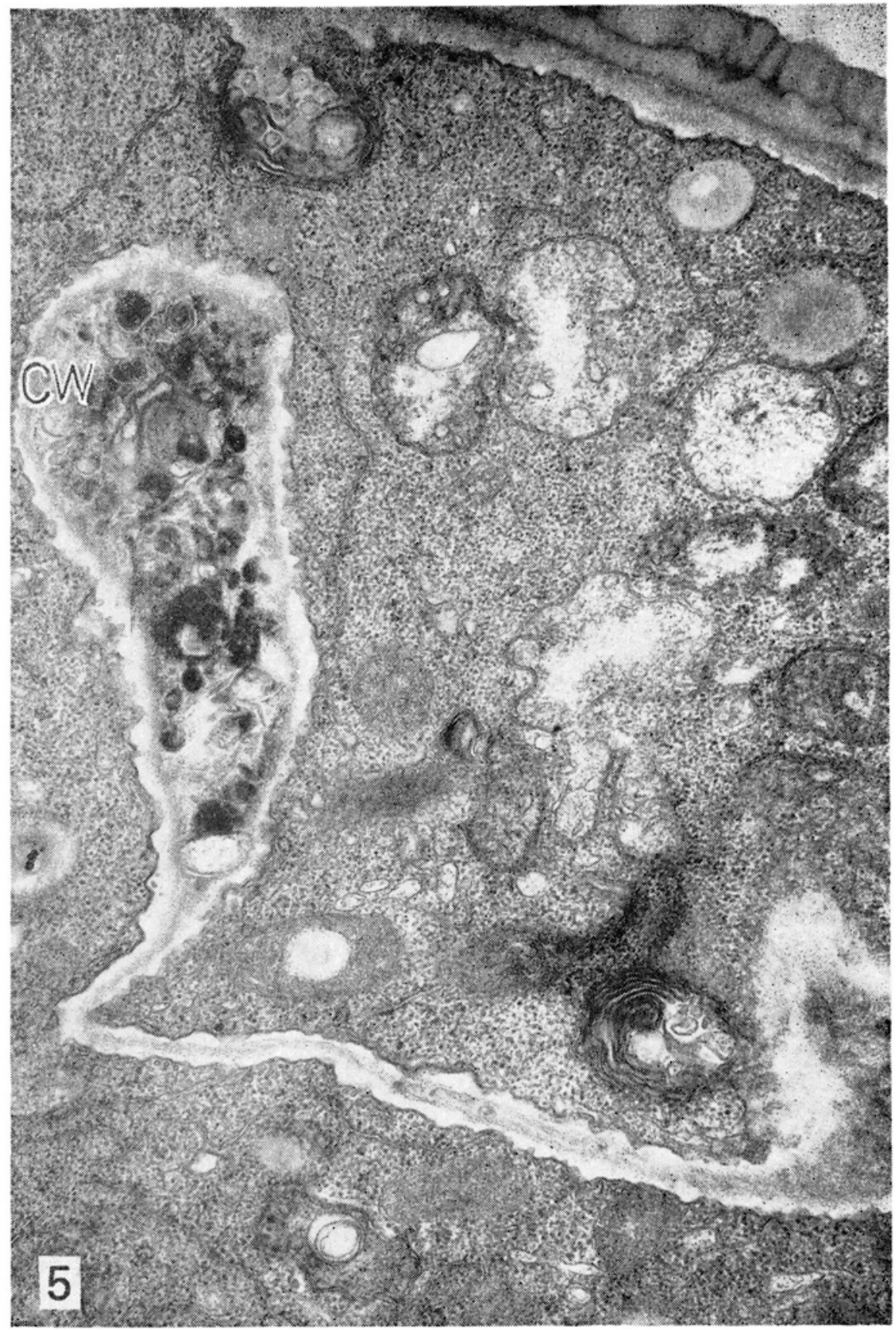

Fig. 5. Wall initial at the intine side (I) and margin of long wall (CW) joing each other. In both many different kinds of inclusions are present. Near the growing wall endoplasmic reticulum (ER). ( $\times 21000)$. 


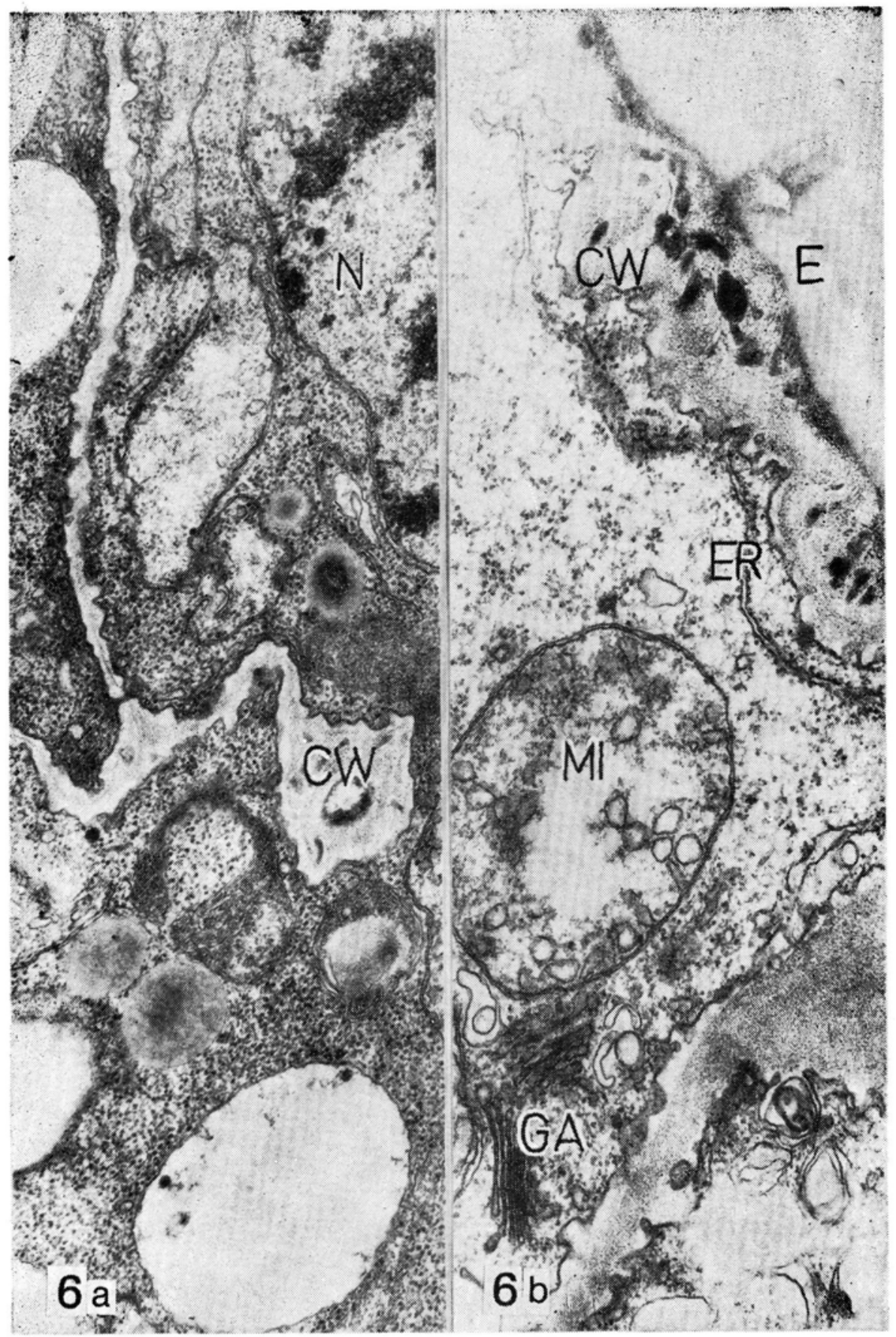

Fig. 6a. Branching cell wall $(\mathrm{CW})$ inside the embryoid. $\mathrm{N}-$ nucleus. $(\times 18000)$. b. Cellulose-containing wall formed on the outer surface of the cell.

E - exine, ER - endoplasmic reticulum, GA - Golgi apparatus, Mi - mitochonrdion. ( $\times 38000)$. 


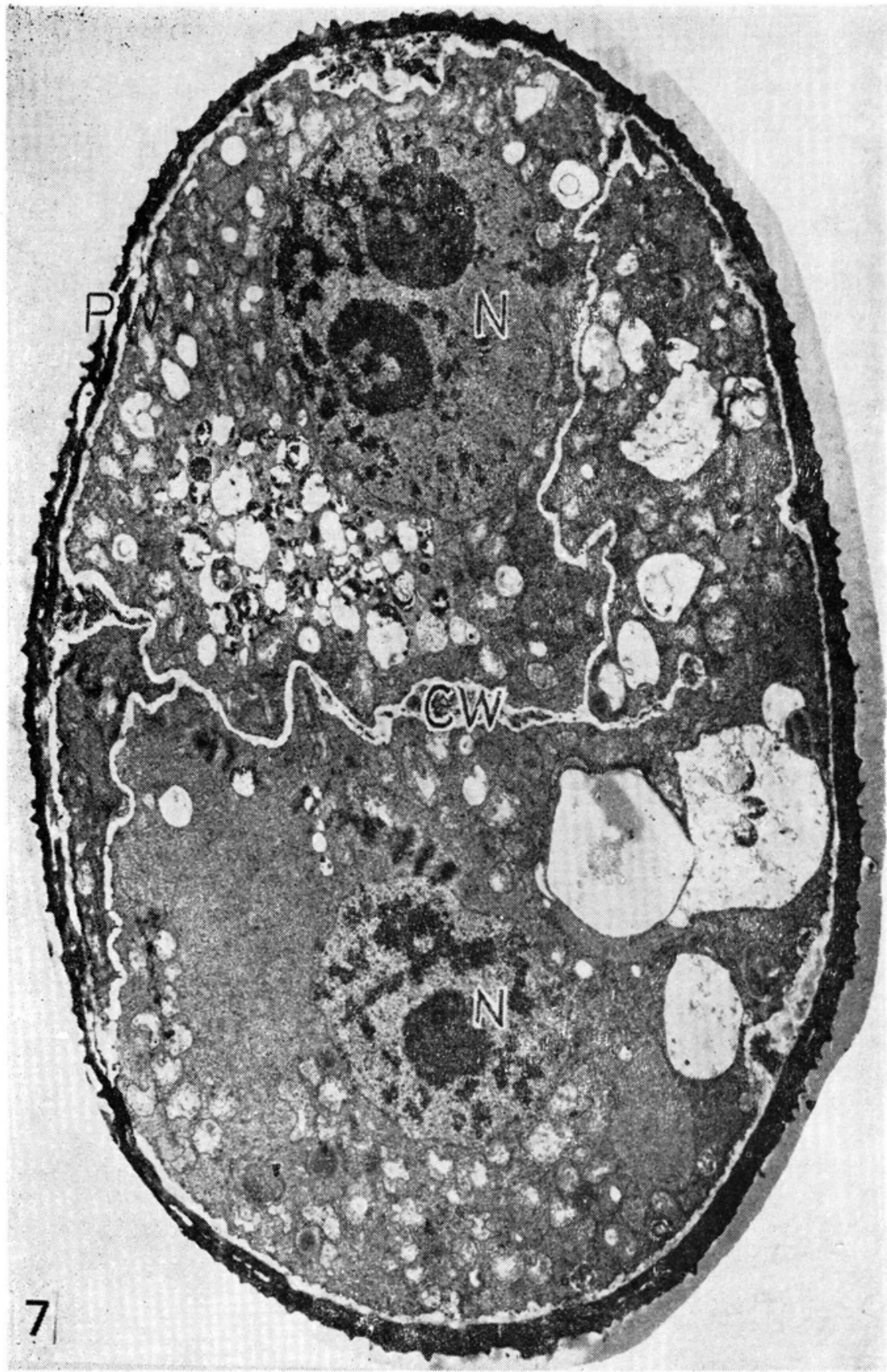

Fig. 7. Several-celled embryoid with visible cell wall patrern. $\mathrm{CW}$ - cell wall, PW - pollen wall, $\mathrm{N}-$ nucleus. $(\times 2700)$. 


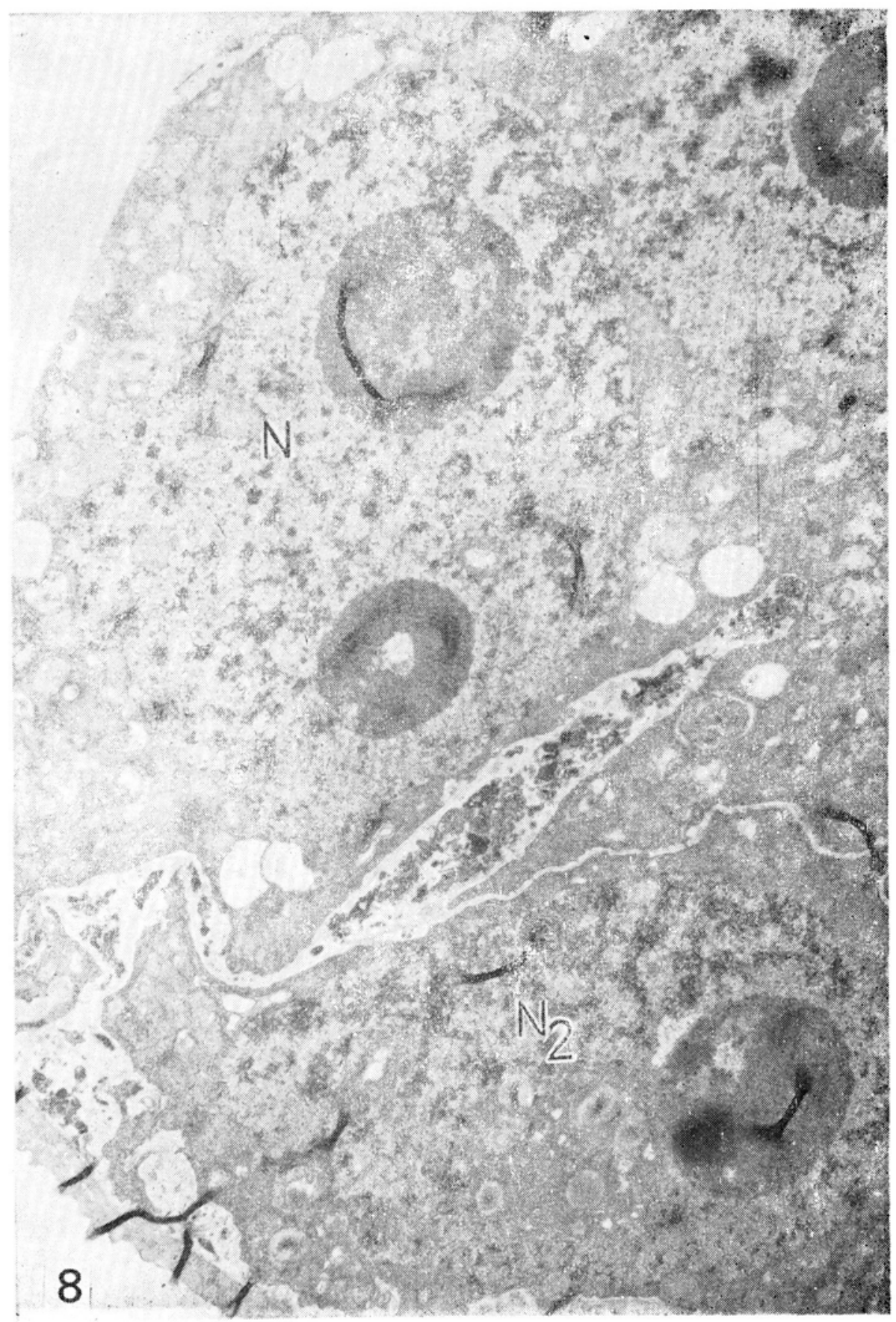

Fig. 8. Nucleus with two nucleoli (N) near the second nucleus $\left(\mathrm{N}_{2}\right)$ in the same cytoplasmic area. $(\times 7000)$. 


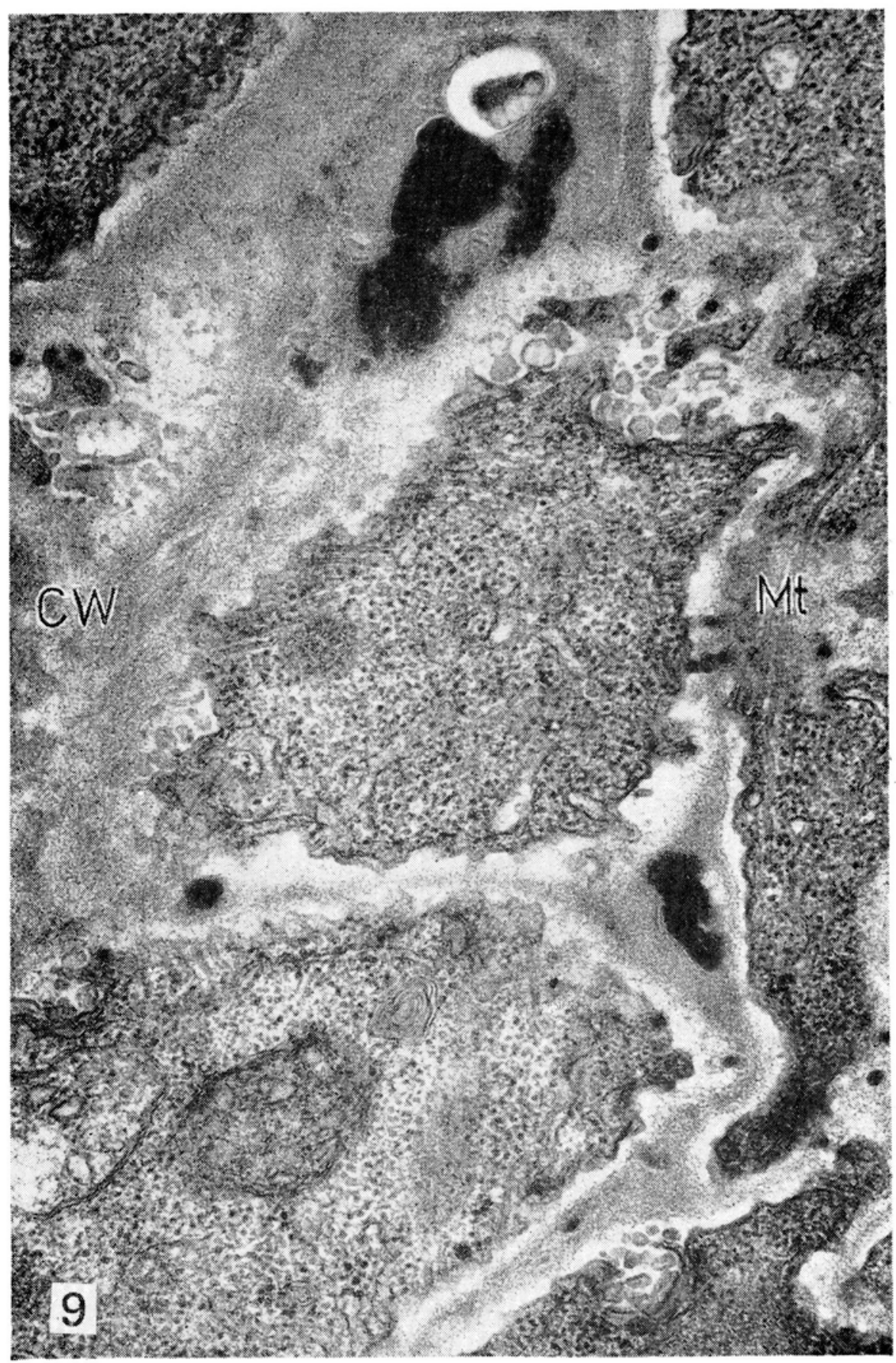

Fig. 9. Cell wall (CW) section in different planes. Mt - microtubules. ( $\times 35000)$. 
reticulum?) could be observed in the cell wall area (Fig. 3b). Also myelin-like structures occurred near the wall (Fig. 4). The cell wall initials grew centripetally from several areas of the intine. On the cross sections they were sinuous and during their further growth they branched and joined to each other (Figs 5 and $6 a$ ).

What decides of the direction of wall growth is unknown, but it was ascertained, that the growing wall may separate cytoplasm fragments containing more than one nucleus (Fig. 7), which can fuse (S u n derla $\mathrm{nd}$, 1974). Thus, it can be one of the reasons responsible for the development of diploid or poliploid cells from Hordeum vulgare pollen in anthers grown in vitro. The cellulose wall also formed on the outer surface of cells in the intine areas (Figs $3 \mathrm{a}$ and $6 \mathrm{~b}$ ). As soon as the exine wall bursts, the about 20 -celled pollen grains of the embryonic cells all have their own wall (Fig. 1).

In cell wall formation such cell components participated as endoplasmic reticulum, plasmalemma and Golgi aparatus (Figs 5 and 6b). All these structures are known to be involved in cell wall formation and differentiation (Robards and Perveen, 1969). Near the cell wall microtubules were also observed (Fig. 9).

The centripetal development of the cell wall in Hordeum pollen is homologous with a primitive type of cell-cleavage known in lower plants (P i c k e t-H e a ps, 1969). A similar cell wall formation as in Hordeum pollen grains was observed during incomplete microspore division in anther cultures of Datura (Dunwell and Sunderland, 1976) and particularly in multinucleate cotton endosperm (J e n s en et al., 1977). In the latter cell walls were initiated at the embryo-sac wall and grew towards the vacuole. Membraneous inclusions in the wall areas of this material were also observed. It may be that the pattern of wall growth in androgenic stimulated multinucleate embryoids of Hordeum and multinucleate endosperm of cotton is very similar.

Acknowledgments

We wish to thank M. Sci. A. Ponitka for cultivating and collecting of material.

\section{REFERENCES}

De Buyser J. and Picard E., 1975. Observation de divisions supplémentaires dans les grains de pollen de plantes homozygotes de blé tendre (Triticum aestivum L.) obtenues par androgenèse in vitro. C. R. Acad. Sc. 281:1153-1156.

$\mathrm{C} 1 \mathrm{a}$ p h m D., 1971. In vitro development of callus from the pollen of Lolium and Hordeum. Z. Pflanzenzüchtg 65:285-292.

Dunwell J. M. and N. Sunderland, 1976. Pollen ultrastructure in anther cultures of Datura innoxia. III. Incomplete microspore division. J. Cell Sci. $22: 493-501$. 
Jensen W. A., P. Schulz, and U. E. Ashton, 1977. An ultrastructural study of early endosperm development and synergid changes in unfertilized cotton ovules. Planta 133:179-190.

M łodzianowski F. and K. Idzikowska, 1978. The ultrastructure on anther wall and pollen of Hordeum vulgare at the microspore stage. Acta Soc. Bot. Pol. 47 (3):219-224.

Picked-Heaps J. D., 1969. The evolution of the mitotic apparatus: an attempt of comparative ultrastructural cytology in dividing plant cells. Cytobios 3: $257-280$.

Reynolds E. S., 1963. The use of lead citrate at high $\mathrm{pH}$ as on electronopaque stain in electron microscopy. J. Cell Biol. 17:208-212.

$\mathrm{Robards} \mathrm{A}$. and $\mathrm{K}$. Parveen, 1969. Vesicular involvement in differentiating plant vasicular cells. New Phytol. 68:343-349.

Sunderland N., 1974. Anther culture as a means of haploid induction. [In:] Proceed. Internat. Symp. on Haploids in Higher Plants. Univ. of Guelph, 91-122.

Ven a ble J. H. and Cogges hall R., 1965. A simplified lead citrate stain for use in electron microscopy. J. Cell Biol. 25:257-408.

Wang Ching-Chu, Chu Chih-Ching, Sun Ching-San, Wu Su - Hsuen, Yin Kwang-Chu, and $\mathrm{Hsu}-\mathrm{Chen}, 1973$. The androgenesis in wheat (Triticum aestivum) anthers cultured in vitro. Scientia Sinica 16: $218-222$.

Wenzel G. and E. Thomas, 1974. Observations on the growth in culture of anthers of Secale cereale. Z. Pflanzenzüchtg 72:89-94.

Wilson H. M., Mix G., and Foroughi-Wehr B., 1978. Early microspore division and subsequent formation of microspore calluses at high frequency in anthers of Hordeum vulgare L. J. Exper. Bot. 29:227-238.

Z enkteler M., 1976. Induction of haploid plants from anthers cultured in vitro. Use of tissue cultures in plant breeding. Olomouc CSSR, 337-354.

Authors's address:

Dr. Krystyna Idzikowska

Adam Mickiewicz University, Laboratory of Electron Microscopy;

Grunwaldzka 6; 60-780 Poznań; Poland Doc. Dr. Fortunat Młodzianowski

Institute of Biology,

Adam Mickiewicz University;

Stalingradzka 14; 61-713 Poznań; Poland

Tworzenie się ściany komórkowej w wielojądrowych ziarnach pytku pylników Hordeum vulgare hodowanych in vitro

Streszczenie

W pracy opisano etapy tworzenia się ściany komórkowej w ziarnach pyłku Hordeum vulgare indukowanych warunkami hodowli in vitro w kierunku androgenezy. Dopiero w kilkujądrowych ziarnach pylku obserwowano zakladanie się ściany komórkowej. Tworzyła się ona nie w wyniku cytokinezy, lecz wrastała z intyny centrypetalnie w głąb wielojądrowego protoplastu. Dodatkowo mogła się „rozgałęziać" dzieląc protoplast na wielokomórkowy embrioid. 